\title{
Quality and Trace Element Profile of Tunisian Olive Oils Obtained from Plants Irrigated with Treated Wastewater
}

\author{
Cinzia Benincasa, ${ }^{1}$ Mariem Gharsallaoui, ${ }^{2}$ Enzo Perri, ${ }^{1}$ Caterina Briccoli Bati, ${ }^{1}$ \\ Mohamed Ayadi, ${ }^{2}$ Moncen Khlif, ${ }^{2}$ and Slimane Gabsi ${ }^{3}$ \\ ${ }^{1}$ Centro di Ricerca per l'Olivicoltura e l'Industria Olearia, CRA, via Li Rocchi 111, 87036 Rende, Italy \\ ${ }^{2}$ Olive Tree Institute, University of Sfax, Route de l'aeroport Km 1.5, BP 1087, 3000 Sfax, Tunisia \\ ${ }^{3}$ National School of Engineering, University of Gabes, Rue Omar Ibn El Khattab 6029, Tunisia
}

Correspondence should be addressed to Cinzia Benincasa, cinzia.benincasa@entecra.it

Received 31 October 2011; Accepted 4 December 2011

Academic Editor: María Luisa de la Torre

Copyright (c) 2012 Cinzia Benincasa et al. This is an open access article distributed under the Creative Commons Attribution License, which permits unrestricted use, distribution, and reproduction in any medium, provided the original work is properly cited.

In the present work the use of treated wastewater (TWW) to irrigate olive plants was monitored. This type of water is characterized by high salinity and retains a substantial amount of trace elements, organic and metallic compounds that can be transferred into the soil and into the plants and fruits. In order to evaluate the impact of TWW on the overall quality of the oils, the time of contact of the olives with the soil has been taken into account. Multi-element data were obtained using ICP-MS. Nineteen elements (Li, B, Na, $\mathrm{Mg}, \mathrm{Al}, \mathrm{K}, \mathrm{Ca}, \mathrm{Sc}, \mathrm{Cr}, \mathrm{Mn}, \mathrm{Fe}, \mathrm{Co}, \mathrm{Ni}, \mathrm{Cu}, \mathrm{Zn}, \mathrm{Sr}, \mathrm{Mo}, \mathrm{Ba}$ and $\mathrm{La}$ ) were submitted for statistical analysis. Using analysis of variance, linear discriminant analysis and principal component analysis it was possible to differentiate between oils produced from different batches of olives whose plants received different types of water. Also, the results showed that there was correlation between the elemental and mineral composition of the water used to irrigate the olive plots and the elemental and mineral composition of the oils.

\section{Introduction}

Tunisia is a very important country in the olive oil producing world, the largest, African exporter and fourth worldwide after Spain, Italy and Greece with an annual average export over 10,000 metric tonnes [1]. The olive tree (Olea europaea L.) is present practically in every region of the country up to the border of the southern desert. Tunisia belongs to the Middle East and North Africa (MENA), which is considered one of the driest regions in the world [2]; in fact, only 30\% of the cultivated area in the region is irrigated but produces about $75 \%$ of the total agricultural production. Alternative water resources are therefore needed to satisfy further increases in demand. Tunisia launched a national water reuse program in the early 1980s to increase usable water resources. Most municipal wastewater is from domestic sources and receives secondary biological treatment. In 2003, 187 million $\mathrm{m}^{3}(78 \%)$ of the 240 million $\mathrm{m}^{3}$ of wastewater collected in Tunisia received treatment. About $30-43 \%$ of the treated wastewater (TWW) was used for agricultural and landscape irrigation [3]. Reusing wastewater for irrigation is viewed as a way to increase water resources, provide supplemental nutrients, and protect coastal areas, water resources, and sensitive receiving bodies. Reclaimed water is used on 8000 ha to irrigate industrial (cotton, tobacco, sugarbeet, etc.) and fodder crops (alfalfa, sorghum, etc.), cereals, vineyards, citrus, and other fruit trees (olives, peaches, pears, apples, pomegranates, etc.). Regulations allow the use of secondary-treated effluent on all crops except vegetables, whether eaten raw or cooked [4]. As it is demonstrated that the olive trees respond favourably and efficiently to the irrigation management [5-7] and as the water resources in Tunisia are limited, the use of nonconventional water can be a good alternative. However, due to the particular characteristics of the water and potential health risks associated with their use in agriculture, it is important that the effects of irrigation with TWW are objectively evaluated. The primary and secondary wastewater treatments improve distinctly the water quality as the treated wastewater still retains a substantial amount of organic, and metallic compounds $[8,9]$ such as carbon, nitrogen, phosphorous, and potassium which have a favourable effect on the growth of certain crops [10]. 
Moreover, the reuse of the TWW can also have important consequences for the irrigated soils as the TWW can change their characteristics and quality due to the process of salinization and pollution by some mineral, organic, and bacteriological materials [10]. Several authors have studied the impact of TWW on the quality of the soils [11-19]. The possibility of transfer metals and trace elements by using TWW into the soil and from the soil to the plant is not well studied. The most commonly used techniques for the determination of metals in oil samples are inductively coupled plasma atomic emission spectrometry (ICP-AES) and atomic absorption spectrometry (AAS) [20]. Fats and oils are particularly difficult to analyze for their trace metal contents since some of them are present at very low concentration levels. For this reason inductively coupled plasma mass spectrometry (ICP-MS) is considered an interesting tool because of its well-known high sensitivity and because it allows a simultaneous quantitative determination of multielements in such a complex matrix [21]. However, since ICP-MS analysis faces many drawbacks, sample needs to be treated in order to eliminate the organic matrix that causes the extinction of the plasma. The aim of this study was, therefore, to determine the impact of TWW used to irrigate olive trees on the quality of the olive oils produced. Since farmers in Tunisia collect fallen olives, especially if the quantity that has dropped is consistent and mix them with olives harvested by hand directly from the tree, it is essential to control also the quality of oils extracted from olives fallen on field irrigated with TWW [22]. Hence, this paper proposes a quantitative analysis of elements in olive oils from Chemlali cultivar produced in Tunisia by means of ICP-MS.

\section{Experimental}

2.1. Olive Sampling and Oil Extraction. The olive samples utilized in this study were collected from experimental plots located in the region of Sfax in central eastern Tunisia in the experimental station of El Hajeb. These experimental plots are characterized by sandy soil, and the use of the TWW is for the irrigation of annual crops in insertion with the olive trees. If olive trees are in insertion with alfalfa they receive water at an annual rate of $10,000 \mathrm{~m}^{3}$ per ha by means of a continuous drip irrigation system. During the experimental years, irrigation was performed every month (continuous irrigation) with the exception of the harvest period that occurred on December and January. If olive trees are in insertion with oats, they receive water at an annual rate of $5,000 \mathrm{~m}^{3}$ per ha by means of a continuous drip irrigation system that was performed from April to May and from October to December (alternate irrigation). Twenty-two-year-old trees spaced $24 * 24 \mathrm{~m}$ were used in block design with three different irrigation systems: (a) olive trees intercropped with alfalfa receiving continuous irrigation with TWW since 2001; (b) olive trees intercropped with oats receiving an alternating irrigation with TWW since 2001; (c) olive trees irrigated with conventional water $(\mathrm{CW})$, (d) olive trees not irrigated (control plants). For each irrigation system, fallen olives were picked from under the trees. The residence time of the olives on the ground is from a few days to several months, and, normally, their moisture percentage content reflects their residence time under the olive trees and then in contact with the soil. Therefore, once collected, olives were sorted according to their moisture percentage content and called as follows: first fall $50.73 \%( \pm 5.31 \%)$, second fall $33.45 \%$ $( \pm 5.15 \%)$, third fall $14.89 \%( \pm 2.62 \%)$ and forth fall $4.22 \%$ $( \pm 0.72 \%)$. The moisture percentage of the olives collected directly from the plant resulted to be $44.22 \%( \pm 7.45 \%)$. For each irrigation system, $3 \mathrm{~kg}$ of olives were milled by means of a laboratory scale hammer mill. After 20 minute of malaxation, the oil was separated by centrifugation.

\subsection{Chemical Characteristics of Treated Wastewater and Con-} ventional Water [23]. In order to remove the biodegradable matters of TWW, biological processes are performed by the action of aerobic microorganisms that, in the presence of oxygen, are able to metabolize the organic matter producing more microorganisms and inorganic end products such as $\mathrm{CO}_{2}, \mathrm{NH}_{3}$, and $\mathrm{H}_{2} \mathrm{O}$. Conventional water (CW) characteristics are quite different from those of TWW. Calculated values of $\mathrm{pH}$ resulted in 7.60 and 7.95 for CW and TWW, respectively, and, as they fall within the range of 6 to 9 , their use can be employed in agriculture [24]. The electrical conductivity for TWW was $6.30 \mathrm{dS} / \mathrm{m}$ while $4.60 \mathrm{dS} / \mathrm{m}$ for $\mathrm{CW}$ indicating, respectively, a high and moderate level of salinity [25]. The concentration of $\mathrm{NH}_{4}{ }^{+}, \mathrm{NO}_{3}{ }^{-}$, and $P_{\text {total }}$ was high $(37.9,15.9$, and $10.3 \mathrm{mg} / \mathrm{mL}$ compared to $2.24,1.11$ and $0.8 \mathrm{mg} / \mathrm{mL}$ of CW, resp.). The concentrations of $\mathrm{Na}^{+}$and $\mathrm{Cl}^{-}$in TWW were $470 \mathrm{mg} / \mathrm{mL}$ and $1999 \mathrm{mg} / \mathrm{mL}$ while, in CW, was $355 \mathrm{mg} / \mathrm{mL}$ and $1580 \mathrm{mg} / \mathrm{mL}$. In both TWW and $\mathrm{CW}$, chloride concentration was higher than the threshold reported by Chartzoulakis in the guidelines for olive irrigation $[26,27]$. The concentrations of $\mathrm{Ca}^{2+}(96 \mathrm{mg} / \mathrm{mL})$ and $\mathrm{Mg}^{2+}(84 \mathrm{mg} / \mathrm{mL})$ were almost half compared with those present in CW. The concentrations of $\mathrm{Zn}^{2+}(0.42 \mathrm{mg} / \mathrm{mL})$ and $\mathrm{Mn}^{2+}(0.5 \mathrm{mg} / \mathrm{mL})$ were four and five times higher than in CW. Although the values of COD and BOD were very high in TWW $(73 \mathrm{mg} / \mathrm{mL}$ and $22 \mathrm{mg} / \mathrm{mL})$ compared to the values in CW, both biological and chemical oxygen demands were below the Tunisian thresholds for water reuse (30 and $90 \mathrm{mg} / \mathrm{mL}$, resp.).

2.3. Physicochemical Analysis of Olive Oils. The olive oils were analysed for their most important physicochemical parameters, that is, free acidity, peroxide index, UV absorption characteristics at 232 and $270 \mathrm{~nm}$, and fatty acid methyl esters according to the official methods of European Union [28].

2.4. Total Phenols Analysis. Total phenols content were determined as described in our previous paper [29]. In brief, $2.5 \mathrm{~g}$ of olive oil were dissolved in hexane and extraction with a solution of methanol and water was performed. The phenolic fraction was determined by mean of Folin-Ciocalteu reagent and quantitation achieved by external calibration curve $\left(r^{2}=\right.$ 0.996) made with caffeic acid purchased from Sigma Aldrich.

2.5. Fatty Acid Methyl Esters (FAMEs) Analysis. Fatty acid methyl esters (FAMEs) analysis were carried out as described 
in our previous paper [30]. FAMEs were analyzed by gas chromatography, and peaks were identified by comparing their retention times with those of authentic reference compounds. The fatty acid composition was expressed as relative percentages of each fatty acid calculated considering the internal normalization of the chromatographic peak area.

\subsection{ICP-MS Analysis}

2.6.1. Materials and Apparatus for ICP-MS Analysis. The ultrapure $\mathrm{HNO}_{3}$ (normaton ultrapure, VWR prolabo) used in this work was acquired by analytical-reagent grade certified for the impurities. Single- and multielement standards (Certipur, Merk, Darmstadt, Germany) were also analytical-reagent grade. Aqueous solutions were prepared using ultrapure water, with a resistivity of $18.2 \mathrm{Mcm}$, obtained from a Milli-Q plus system (Millipore, Saint Quentin Yvelines, France). All glassware were decontaminated with nitric acid $(2 \%, v / v)$ for at least two hours, rinsed with ultrapure water, and dried. The experimental work was carried out using a Milestone MLS-1200 MEGA oven system for the microwave digestion. The determination of the elements of interest was carried out by means of an Agilent 7500e ICP-MS instrument (Agilent Technologies, Santa Clara, USA) where oil samples were introduced by means of a quartz nebulizer. The ICP torch was a standard torch equipped with platinum injector. As the performance of the ICP-MS instrument strongly depends on the operating conditions [31], a solution containing $\mathrm{Rh}, \mathrm{Mg}$, $\mathrm{Pb}, \mathrm{Ba}$ and $\mathrm{Ce}(10 \mathrm{~g} / \mathrm{L})$ was used to optimize the instrument in terms of sensitivity, resolution, and mass calibration. The ${ }^{140} \mathrm{Ce}^{16} \mathrm{O}^{+} /{ }^{140} \mathrm{Ce}^{+}$ratio was used to check the level of oxide ions in the plasma that could interfere in the determination of some elements; also, instrumental parameters such as RF power and carrier gas flow were optimized and the level of doubly charged ion monitored by means of the signal ${ }^{137} \mathrm{Ba}^{2+} /{ }^{137} \mathrm{Ba}^{+}$. ICP-MS analysis was performed following the operating program and parameters as follows: plasma power: $1150 \mathrm{~W}$; nebuliser: glass concentric type; carrier gas flow rate: $1.05 \mathrm{l} / \mathrm{min}$; oxide ratios: $<3 \%(\mathrm{CeO} / \mathrm{Ce})$; double charged species: $<2 \%\left(\mathrm{Ba}^{2+} / \mathrm{Ba}^{+}\right)$; sample uptake rate: $1.2 \mathrm{~mL} / \mathrm{min}$; coolant argon flow: $17 \mathrm{l} / \mathrm{min}$; sweeps/reading: 45; readings/replicate: 3; replicates: 3; dwell time: $55 \mathrm{~ms}$; scan mode: peak hopping; isotopes monitored: ${ }^{7} \mathrm{Li}^{+},{ }^{9} \mathrm{Be}^{+}$, ${ }^{10} \mathrm{~B}^{+},{ }^{23} \mathrm{Na}^{+},{ }^{25} \mathrm{Mg}^{+},{ }^{27} \mathrm{Al}^{+},{ }^{29} \mathrm{Si}^{+},{ }^{31} \mathrm{P}^{+},{ }^{34} \mathrm{~S}^{+},{ }^{39} \mathrm{~K}^{+},{ }^{43} \mathrm{Ca}^{+}$, ${ }^{45} \mathrm{Sc}^{+},{ }^{49} \mathrm{Ti}^{+},{ }^{51} \mathrm{~V}^{+},{ }^{53} \mathrm{Cr}^{+},{ }^{55} \mathrm{Mn}^{+},{ }^{57} \mathrm{Fe}^{+},{ }^{59} \mathrm{Co}^{+},{ }^{62} \mathrm{Ni}^{+},{ }^{65} \mathrm{Cu}^{+}$, ${ }^{66} \mathrm{Zn}^{+},{ }^{74} \mathrm{Ge}^{+},{ }^{75} \mathrm{As}^{+},{ }^{82} \mathrm{Se}^{+},{ }^{88} \mathrm{Sr}^{+},{ }^{89} \mathrm{Y}^{+},{ }^{90} \mathrm{Zr}^{+},{ }^{93} \mathrm{Nb}^{+},{ }^{95} \mathrm{Mo}^{+}$, ${ }^{111} \mathrm{Cd}^{+},{ }^{121} \mathrm{Sb}^{+},{ }^{139} \mathrm{La}^{+},{ }^{140} \mathrm{Ce}^{+},{ }^{141} \mathrm{Pr}^{+},{ }^{145} \mathrm{Nd}^{+},{ }^{147} \mathrm{Sm}^{+}$, ${ }^{151} \mathrm{Eu}^{+},{ }^{158} \mathrm{Gd}^{+},{ }^{159} \mathrm{~Tb}^{+},{ }^{163} \mathrm{Dy}^{+},{ }^{165} \mathrm{Ho}^{+},{ }^{169} \mathrm{Tm}^{+},{ }^{173} \mathrm{Yb}^{+}$, ${ }^{175} \mathrm{Lu}^{+},{ }^{181} \mathrm{Re}^{+},{ }^{205} \mathrm{Tl}^{+},{ }^{208} \mathrm{~Pb}^{+},{ }^{232} \mathrm{Th}^{+}$.

2.6.2. Sample Preparation. Sample preparation was performed as reported in Benincasa et al. [21]. Briefly, each olive oil sample was homogenized by vigorous shaking, and $0.5 \mathrm{~g}$ was weighed directly into the digestion vessel where nitric acid was added.

Olive oil samples were digested and analysed three times in order to check the sensitivity and reproducibility of the digestion procedure. The operating program for the microwave digestion system consisted of 6 steps, and the total time of the digestion procedure lasted 31 minutes. After cooling at room temperature, all the digestion liquors were quantitatively transferred into volumetric flask and diluted to volume $(30 \mathrm{~mL})$ with ultrapure water. An analytical batch contained 3 procedural blanks and two procedural blanks spiked with a standard solution containing 48 elements. A mid-range calibration standard was measured at the end of each analytical run, for quality control purposes, that is, to assess instrumental drift throughout the run. Limits of quantitations (LOQs) were defined as 10 times the standard deviation of the signal from reagent blanks, after correction for sample weight and dilution. All the elements that were below this value were not accepted for statistical analysis.

2.6.3. Calibration Procedure. In order to quantify the elements in the oils, external calibration curves were build on five different concentrations. Standard solutions were prepared by diluting a multielement solution of Ce, Dy, Er, Eu, Gd, Ho, La, Lu, Nd, Pr, Sm, Sc, Tb, Th, Tm, Y, and Yb at $10 \mathrm{mg} / \mathrm{mL}$; a multielement solution of $\mathrm{Ag}, \mathrm{Al}, \mathrm{B}, \mathrm{Ba}, \mathrm{Bi}, \mathrm{Ca}$, $\mathrm{Cd}, \mathrm{Co}, \mathrm{Cr}, \mathrm{Cu}, \mathrm{Fe}, \mathrm{K}, \mathrm{Li}, \mathrm{Mg}, \mathrm{Mn}, \mathrm{Mo}, \mathrm{Na}, \mathrm{Ni}, \mathrm{Pb}, \mathrm{Sr}, \mathrm{Tl}$, and $\mathrm{Zn}$ at $100 \mathrm{mg} / \mathrm{mL}$; a multielement solution of $\mathrm{Au}, \mathrm{Ge}$, $\mathrm{Pt}, \mathrm{Sn}, \mathrm{Ti}$, and $\mathrm{Zr}$ at $10 \mathrm{mg} / \mathrm{mL}$; a solution of Si, S, and $\mathrm{P}$ at $1000 \mathrm{mg} / \mathrm{mL}$. The concentration range for the elements were between $0.01-100 \mathrm{mg} / \mathrm{mL}$ and $0.2-2000 \mathrm{mg} / \mathrm{mL}$. Two spike solutions were used as a recovery test.

2.7. Statistical Analysis. All statistical treatment was performed by STATGRAPHICS Plus Version 5.1 (Statistical Graphics Corporation, Professional Edition-Copyright 19942001).

The statistical approach that has been chosen to analyse the set of data obtained by ICP-MS was principal component analysis (PCA) and linear discriminant analysis (LDA).

Also, in order to check possible differences between the oils, two-way analysis of variance (ANOVA) was performed considering, as main factors, the irrigation regimes and the type of irrigation water. Moreover, to evaluate significant differences between averages, Tukey test was performed on the oil quality parameters. Differences were considered statistically significant for $P \geq 0.01$ (capital letters) and $P \geq$ 0.05 (small letters). The values obtained for free acidity and FAMEs were statistically analyzed after arcsine transformation in order to meet assumptions for ANOVA. However, the results are presented in their original scale of measurement and reported as the averages of three repetitions $(n=3)$.

\section{Result and Discussions}

3.1. Physicochemical Analysis of Olive Oils. The most important quality parameters of the oils analysed in this study are listed in Table 1. In general, oils obtained from olives whose plants were irrigated with TWW were found to be "lampanti" characterized by high values of free acidity and low values of polyphenols. This result could be explained by considering that the quality of edible oils and fats is effected by their concentrations of trace metals $[32,33]$. Traces of 


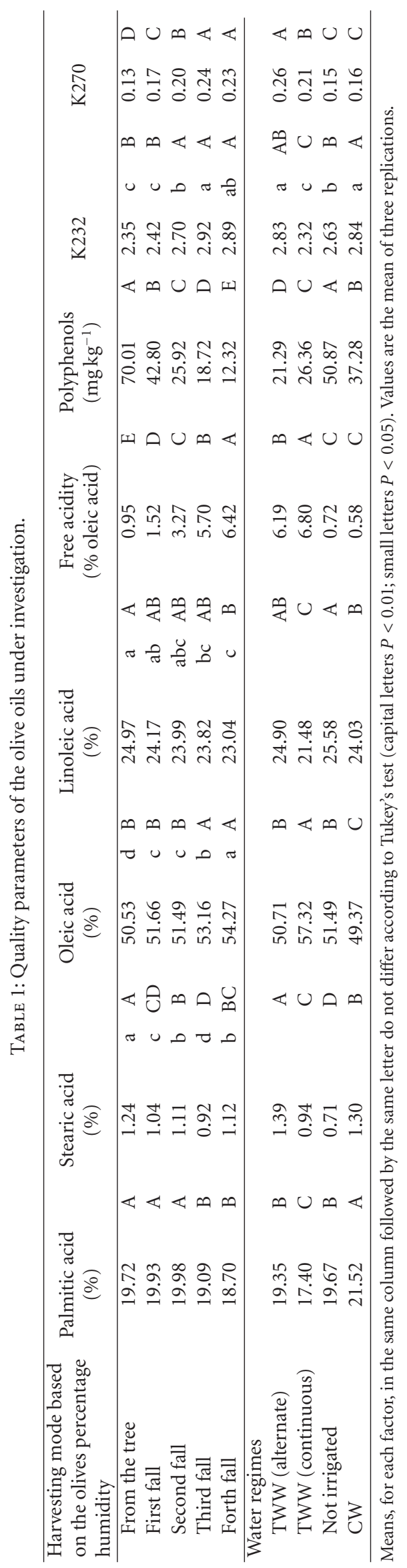


metals in edible oils are known to have an effect on the rate of oil oxidation, decreasing the shelf life of commercial products [34]. Apart from causing premature rancidity, these oxidation processes may generate peroxides, aldehydes, ketones, acids, epoxides, and other compounds that may cause effects in the digestive system and also react with other food components (proteins and pigments), sensitising the action of some carcinogens [35].

3.2. Free Fatty Acid. Analysis of variance (ANOVA) applied to the values of free acidity has clearly made a distinction between the oils under investigation. Considering as main factors the harvesting mode, oils obtained from olives that remained in contact with the soil for a short period gave a value of free acidity comprised in a range between 1.52 and $3.27 \%$, while oils obtained from olives that stayed for longer periods gave values up to $6.42 \%$. Oils obtained from olives harvested directly from the plants gave a value of $0.95 \%$.

Considering the second factor being the water regime, oils obtained from olives whose plants were irrigated with TWW were found to be of poor quality and characterized by high values of free acidity. However, we must point out that oils produced from olives harvested directly from the plant (control plants) gave a value of free acidity of $6.19 \%$ in an alternate irrigation regime with TWW and $6.80 \%$ in a continuous one; $0.72 \%$ in the rain-fed regime and $0.58 \%$ in the conventional water one (Table 1).

3.3. Polyphenols. Considering the first factor analysed being the harvesting mode, it is highly evident that the most abundant content of polyphenols is found in the oils produced from olives harvested directly from the plants. This value decreases significantly increasing the contact of the fruits with the soil. In fact, the polyphenols content of oils produced by processing the fruits collected from the ground in the last period of the harvest was very low $(12.32 \mathrm{mg} / \mathrm{kg})$. Considering the second factor being the water regime; the content of polyphenols found in the oils obtained from olives belonging to the rainfed regime resulted to be statistically different from all the other values $(50.87 \mathrm{mg} / \mathrm{kg})$. This value decreases significantly within the water regime, in fact, oils coming from plant irrigated with TWW gave values of 26.36 and $21.29 \mathrm{mg} / \mathrm{kg}$ for the continuous and alternate system, respectively, while $37.28 \mathrm{mg} / \mathrm{kg}$ for the conventional one (Table 1).

3.4. Fatty Acid Methyl Esters (FAMEs). In general, the fatty acid content is typical of Tunisian oils $[36,37]$. However, the oils under analysis were dominated by palmitic acid (C16: 0 ), stearic acid (C18: 0 ), oleic acid (C18: 1), and linoleic acid (C18: 2) (Table 1). In this study, the observed values do not show a particular pattern that can explain the permanence of the olives with the soil and the incidence of the different water irrigation regimes on the quality of the oils obtained. In fact, the fatty acids of an olive oil are not dependent on the processing and harvesting of the olives but rather depend on genetic factors $[38,39]$.
3.5. Quality Control and Quality Assurance Data of ICP-MS Analysis. Initially, 48 elements were investigated but only 19 were submitted for statistical analysis. The criteria utilized to select those elements were as follows: recovery data were accepted if results were in the range of 70-120\%, with $80 \%$ within $80-110 \%$ and for CRM values, within $20 \%$. The results must be not below the limit of detection (LOD). The replicate agreement was considered acceptable if the value of the RSD was minor of $10 \%$. Table 2 details the LOD values and the percentage recovery of a known amount of analytes spiked for all the elements submitted for statistical analysis. Results from spikes and recovery experiments at levels of 30,80 , and $300 \mathrm{ng} / \mathrm{mL}$ were in the range $92-104 \%$, for almost all the elements. $\mathrm{Li}, \mathrm{Ca}$, and $\mathrm{Ge}$ gave a value of 74,80 , and $87 \%$, respectively, whereas $\mathrm{Ba}$ and $\mathrm{Tl}$ gave a value of 111 and $120 \%$, respectively. Furthermore, it can be seen from Table 2, the values of LODs which were in the range of $0.000-0.051 \mathrm{mg} / \mathrm{kg}$, for almost all the elements. Fe, Ca, Al and $\mathrm{Mg}$ gave a value of $0.294,0.587,0.953$, and $5.118 \mathrm{mg} / \mathrm{kg}$ respectively. Values of LOQs were in the range of $0.000-$ 0.400 for almost all the elements except for $\mathrm{Fe}, \mathrm{K}, \mathrm{Ca}, \mathrm{Al}$ and $\mathrm{Mg}$ that gave a value of $0.980,1.068,1.956,3.178$, and $17.061 \mathrm{mg} / \mathrm{kg}$ respectively. The relative standard deviations of the elements were less than $2 \%$ for all the elements.

3.6. Statistical Analysis of Multielement Data. At first, the trace elements profile and the minerals content present in the oils obtained from olives harvested from the ground irrigated with TWW have been monitored (Table 3). In order to develop a model to discriminate among the 5 levels of type of olive (see Olive Sampling and Oil Extraction), 90 cases (30 olive oil samples three time replicated) were used and 19 predictor variables ( $\mathrm{Li}, \mathrm{B}, \mathrm{Na}, \mathrm{Mg}, \mathrm{Al}, \mathrm{K}, \mathrm{Ca}, \mathrm{Sc}, \mathrm{Cr}, \mathrm{Mn}, \mathrm{Fe}$, $\mathrm{Co}, \mathrm{Ni}, \mathrm{Cu}, \mathrm{Zn}, \mathrm{Sr}, \mathrm{Mo}, \mathrm{Ba}$, and $\mathrm{La}$ ) were entered. The LDA plot resulting is showed in Figure 1, while Table 4 lists the summing up of the analyses of the discriminating functions.

The scores of the first two functions produced from LDA showed a separation into 3 groups: a first group is represented only by oils produced from olives hand picked from the plant (control plants) independently of irrigation regime, a second group is formed by oils produced from olives that stayed in contact with the ground for a short period and having a moisture containing comprised between 50.73\% and $33.45 \%$ (1st and 2nd fall), and a third group formed by oils produced from olives that stayed in contact with the ground for very long time and having a moisture containing comprised in a range of $14.89 \%$ and $4.22 \%$ ( $3 \mathrm{rd}$ and 4 th fall).

In particular, the control plants produced oils with a lower concentration of trace elements and minerals. These oils are lying in the lower left portion of the plot function characterized by negative values.

The oils produced from olives collected from the ground after a short permanence are characterized by higher values of $\mathrm{Na}, \mathrm{K}, \mathrm{Ni}, \mathrm{La}, \mathrm{Sr}, \mathrm{B}$, and Mo, while those produced from olives collected from the ground after a longer period are characterized by higher values of $\mathrm{Li}, \mathrm{Cu}, \mathrm{Fe}, \mathrm{Mn}$, and $\mathrm{Sc}$ (Table 4).

In order to verify the reliability of the model, the method has been tested using known samples as unknown variables. 
TABLE 2: Limit of quantitations (LOQs), limit of detections (LODs), percentage recovery of spike solutions analysed by ICP-MS.

\begin{tabular}{|c|c|c|c|c|}
\hline & Spike 1 (rec.) & Spike 2 (rec.) & LOD & LOQ \\
\hline & $\%$ & $\%$ & $\mathrm{mg} \mathrm{kg}^{-1}$ & $\mathrm{mg} \mathrm{kg}^{-1}$ \\
\hline${ }^{7} \mathrm{Li}$ & 84 & 74 & 0,005 & 0,016 \\
\hline${ }^{10} \mathrm{~B}$ & 96 & 89 & 0,051 & 0,170 \\
\hline${ }^{23} \mathrm{Na}$ & 95 & 90 & 0,104 & 0,347 \\
\hline${ }^{25} \mathrm{Mg}$ & 109 & 95 & 5,118 & 17,061 \\
\hline${ }^{27} \mathrm{Al}$ & 96 & 98 & 0,953 & 3,178 \\
\hline${ }^{39} \mathrm{~K}$ & 100 & 97 & 0,319 & 1,063 \\
\hline${ }^{43} \mathrm{Ca}$ & 80 & 74 & 0,587 & 1,956 \\
\hline${ }^{45} \mathrm{Sc}$ & 103 & 96 & 0,000 & 0,000 \\
\hline${ }^{49} \mathrm{Ti}$ & 104 & 103 & 0,025 & 0,084 \\
\hline${ }^{53} \mathrm{Cr}$ & 104 & 103 & 0,000 & 0,000 \\
\hline${ }^{55} \mathrm{Mn}$ & 104 & 102 & 0,012 & 0,039 \\
\hline${ }^{57} \mathrm{Fe}$ & 92 & 90 & 0,294 & 0,980 \\
\hline${ }^{59} \mathrm{Co}$ & 105 & 104 & 0,005 & 0,015 \\
\hline${ }^{62} \mathrm{Ni}$ & 105 & 105 & 0,011 & 0,038 \\
\hline${ }^{65} \mathrm{Cu}$ & 104 & 104 & 0,000 & 0,000 \\
\hline${ }^{74} \mathrm{Ge}$ & 87 & 69 & 0,000 & 0,000 \\
\hline${ }^{88} \mathrm{Sr}$ & 106 & 103 & 0,006 & 0,019 \\
\hline${ }^{90} \mathrm{Zr}$ & 101 & 101 & 0,039 & 0,130 \\
\hline${ }^{95} \mathrm{Mo}$ & 103 & 101 & 0,028 & 0,092 \\
\hline${ }^{111} \mathrm{Cd}$ & 92 & 92 & 0,000 & 0,000 \\
\hline${ }^{118} \mathrm{Sn}$ & 99 & 93 & 0,000 & 0,000 \\
\hline${ }^{137} \mathrm{Ba}$ & 111 & 108 & 0,007 & 0,023 \\
\hline${ }^{139} \mathrm{La}$ & 103 & 102 & 0,017 & 0,056 \\
\hline${ }^{140} \mathrm{Ce}$ & 102 & 101 & 0,000 & 0,000 \\
\hline${ }^{141} \mathrm{Pr}$ & 103 & 102 & 0,000 & 0,000 \\
\hline${ }^{145} \mathrm{Nd}$ & 103 & 104 & 0,000 & 0,000 \\
\hline${ }^{147} \mathrm{Sm}$ & 104 & 103 & 0,000 & 0,000 \\
\hline${ }^{151} \mathrm{Eu}$ & 103 & 102 & 0,000 & 0,000 \\
\hline${ }^{158} \mathrm{Gd}$ & 104 & 103 & 0,000 & 0,000 \\
\hline${ }^{159} \mathrm{~Tb}$ & 102 & 101 & 0,000 & 0,000 \\
\hline${ }^{163}$ Dy & 104 & 102 & 0,000 & 0,000 \\
\hline${ }^{165} \mathrm{Ho}$ & 101 & 100 & 0,000 & 0,000 \\
\hline${ }^{166} \mathrm{Er}$ & 104 & 103 & 0,000 & 0,000 \\
\hline${ }^{169} \mathrm{Tm}$ & 102 & 101 & 0,000 & 0,000 \\
\hline${ }^{173} \mathrm{Yb}$ & 104 & 102 & 0,000 & 0,000 \\
\hline${ }^{175} \mathrm{Lu}$ & 102 & 101 & 0,000 & 0,000 \\
\hline${ }^{205} \mathrm{Tl}$ & 120 & 115 & 0,000 & 0,000 \\
\hline${ }^{208} \mathrm{~Pb}$ & 109 & 105 & 0,000 & 0,000 \\
\hline${ }^{209} \mathrm{Bi}$ & 108 & 103 & 0,000 & 0,000 \\
\hline${ }^{232} \mathrm{Th}$ & 101 & 100 & 0,006 & 0,021 \\
\hline
\end{tabular}

In particular, a set of 5 samples, composed of one sample for each category of olives, was randomly removed for five times and the model was recalculated. Amongst the $90 \mathrm{ob}-$ servations used to fit the model, 78 or $86.67 \%$ were correctly classified.

Accordingly, by the PCA applied to the concentration of the 19 elements of each single sample, 5 principal com-
TABLE 3: Summing up of the analyses of the discriminating functions.

(a)

\begin{tabular}{lccc}
\hline $\begin{array}{l}\text { Discriminant } \\
\text { function }\end{array}$ & Eigenvalue & $\begin{array}{c}\text { Relative } \\
\text { percentage }\end{array}$ & $\begin{array}{c}\text { Canonical } \\
\text { correlation }\end{array}$ \\
\hline 1 & 5.71366 & 73.38 & 0.92252 \\
2 & 0.994461 & 12.77 & 0.70612 \\
3 & 0.711944 & 9.14 & 0.64488 \\
4 & 0.366289 & 4.7 & 0.51777 \\
\hline
\end{tabular}

(b)

\begin{tabular}{lcccc}
\hline $\begin{array}{l}\text { Functions } \\
\text { derived }\end{array}$ & Wilks $\lambda$ & Chi-Square & DF & $P$ value \\
\hline 1 & 0.0319289 & 265.2069 & 76 & 0.0000 \\
2 & 0.2143590 & 118.5878 & 54 & 0.0000 \\
3 & 0.4275310 & 65.4290 & 34 & 0.0010 \\
4 & 0.7319100 & 24.0316 & 16 & 0.0888 \\
\hline
\end{tabular}

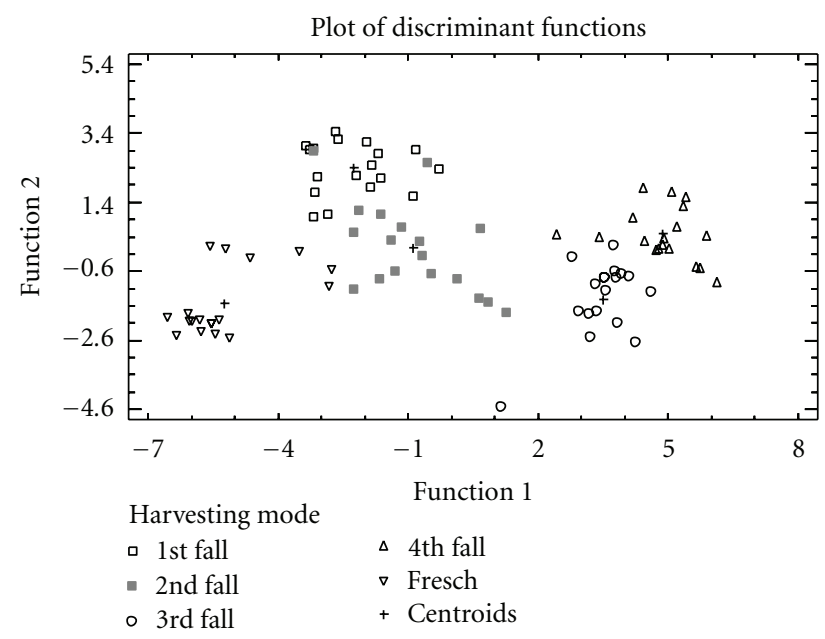

FIGURE 1: LDA plot for 90 olive oil samples (30 samples repeated three times) based on the concentration of 19 elements and using as input a priori five groups, that is, those corresponding to the olives harvested directly from the plants, called fresh, and those that have fallen naturally and stayed in contact with the soil irrigated with TWW. The moisture percentage of the olives were as follows: $50.73 \%( \pm 5.31 \%)$ called 1 st fall; $33.45 \%( \pm 5.15 \%)$ called 2 nd fall; $14.89 \%( \pm 2.62 \%)$ called 3rd fall; $4.22 \%( \pm 0.72 \%)$ called 4 th fall.

ponents have been extracted, having Eigenvalues greater than or equal to 1.0, and together they account for $71 \%$ of the variability in the original data. The elements that mainly contributed to the separation of the groups are $\mathrm{Al}, \mathrm{Sr}, \mathrm{Ba}$, and $\mathrm{Mg}$ on $\mathrm{PC} 1$ and $\mathrm{Na}, \mathrm{K}$, and $\mathrm{Cr}$ on PC 2.

In a second time, LDA was applied to the data set considering as input a priori the irrigation regimes. The bidimensional plot of the first two functions shows a clean separation into 2 groups: oils produced from olives whose plants were irrigated with TWW (in a continuous and alternate regime) and oils obtained from olives whose plants were irrigated with CW (Figure 2). 


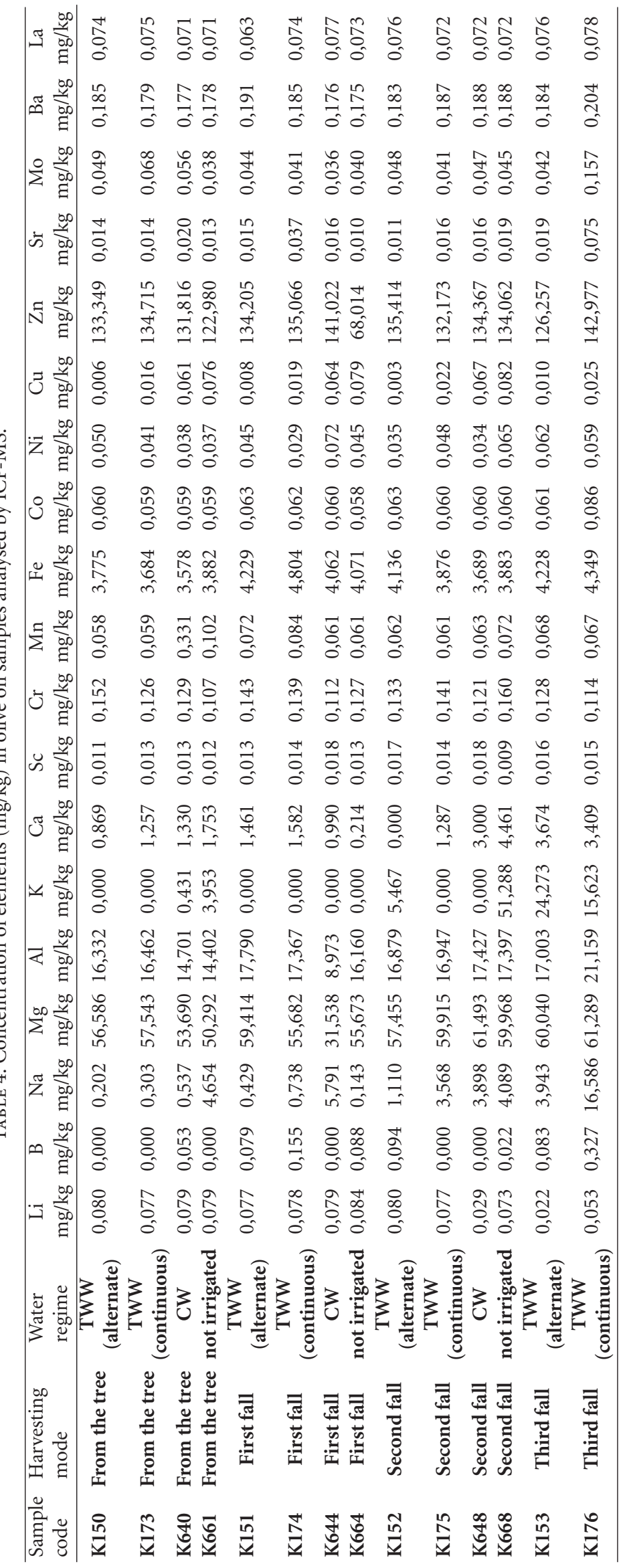




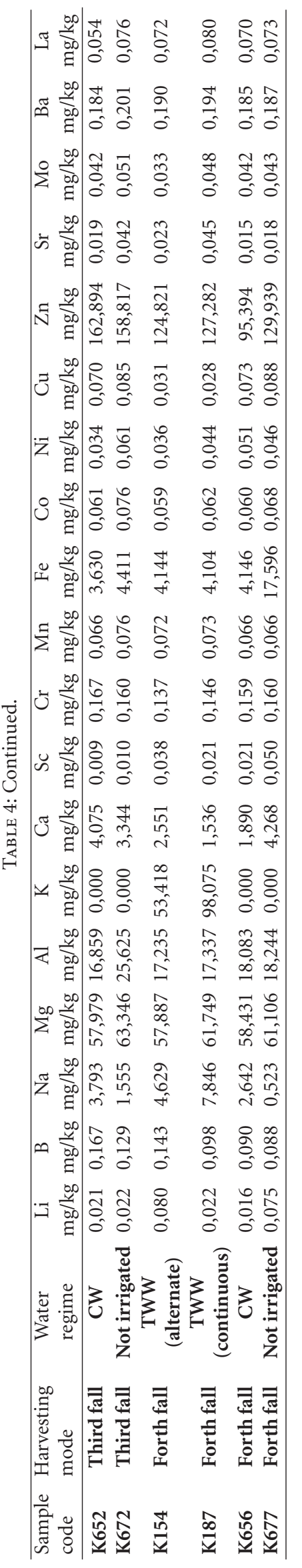




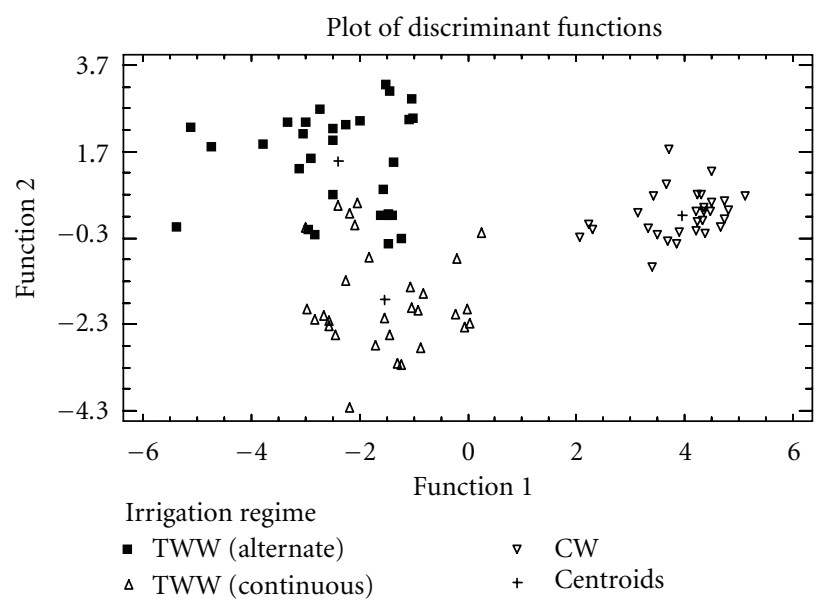

Figure 2: LDA plot for 90 olive oil samples (30 samples repeated three times) based on the concentration of 19 elements and using as input a priori three groups, that is, those corresponding to the irrigation regimes: alternate and continuous using TWW and CW.

Amongst the 90 observations used to fit the model, 79 or $88 \%$ were correctly classified. When PCA was applied, 7 components have been extracted having Eigenvalues greater than or equal to 1.0 , and together they account for $74 \%$ of the variability in the original data. The elements that mainly contributed to the separation of the groups are mainly $\mathrm{Sc}, \mathrm{Mn}, \mathrm{Li}$, $\mathrm{Cu}, \mathrm{Fe}, \mathrm{La}, \mathrm{Ni}, \mathrm{K}$, and $\mathrm{Na}$ on $\mathrm{PC} 1$ and $\mathrm{Mg}, \mathrm{Ba}, \mathrm{Al}, \mathrm{Ca}, \mathrm{Sr}$ and $\mathrm{B}$ on $\mathrm{PC} 2$.

\section{Conclusions}

The development of rapid and accurate analytical methods for the determination of metal concentrations in edible oils and fats is still a challenge in terms of quality control analysis, owing to the low concentration levels of some elements and the difficulties that arise due to the characteristics of the matrix $[21,40]$. The metals analysed in this study, particularly $\mathrm{Fe}, \mathrm{Cu}, \mathrm{Ca}, \mathrm{Mg}, \mathrm{Ni}$, and $\mathrm{Mn}$, are known to increase the rate of oil oxidation $[41,42]$.

Statistical analysis clearly showed how the way to harvest the olives strongly influences the quality of oils produced [32]. Oils obtained from olives harvested from the ground were found in fact to be of poor quality. This data is not surprising considering that these olives are source of fermentation processes that lead to high values of free acidity and very low values of phenolic compounds in the oil. Moreover, if we consider the contact of the olives with the moist soil, surely the produced oil will be marked by the negative attribute of mould and ground. All the ICP-MS results and statistical evaluations performed have showed that oils produced from olives harvested from the ground have a richer trace elemental and mineral profile than oils produced from olives picked directly from the plant. In particular, olive trees irrigated with treated wastewater produced oils even richer in trace elements and minerals.

The European Community sets limit only for PB in edible oils, which is $0.1 \mathrm{mg} / \mathrm{kg}$ (European Commission 2006) [43]; for the other elements, no limits are set and their concentrations could be a concern for consumers.

Therefore, this study has pointed out that the irrigation with TWW adversely affects the quality of the oils. In fact, the olive oils were found to be "lampanti" characterized by high values of free acidity and very low values of polyphenols. Although the availability of wastewater is a very interesting alternative for urban agriculture, the health risks associated with this practice can constitute a real obstacle to the development of this activity.

\section{Acknowledgments}

This work was supported by "Riom II-Risorse aggiuntive" project sponsored by MIPAF (D.M. MiPAF no. 92691 del 18.12.03), the Tunisian Ministry of Higher Education, Scientific Research and Technology, and the Institution of Agricultural Research and Higher Education (IRESA). The authors thank M. J. Duff for English revision. Cinzia Benincasa and Mariem Gharsallaoui have participated equally to this work.

\section{References}

[1] IOOC, Olive oil exportations. International Olive Oil Council, 2004, http://www.internationaloliveoil.org.

[2] World Bank. From Scarcity to Security: Averting a Water Crisis in the Middle East and North Africa, World Bank, Washington, DC, USA, 1995.

[3] M. Qadir, D. Wichelns, L. Raschid-Sally et al., "The challenges of wastewater irrigation in developing countries," Agricultural Water Management, vol. 97, no. 4, pp. 561-568, 2010.

[4] A. N. Angelakis, M. H. F. Marecos Do Monte, L. Bontoux, and T. Asano, "The status of wastewater reuse practice in the Mediterranean basin: need for guidelines," Water Research, vol. 33, no. 10, pp. 2201-2217, 1999.

[5] C. Briccoli Bati, P. Basta, C. Tocci, and D. Turco, "Influence of irrigation with brackish water on young olive plants," Olivae, vol. 53, pp. 35-38, 1994.

[6] G. Celano, B. Dichio, G. Montanaro, V. Nuzzo, A. M. Palese, and C. Xiloyannis, "Distribution of dry matter and amount of mineral elements in irrigated and non-irrigated olive trees," Acta Horticulturae, vol. 474, pp. 381-384, 1999.

[7] H. Chehab, D. Boujnah, M. Braham, and S. Ben Elhadj, "Effets de trois régimes hydriques sur les comportements biologiques et agronomiques de deux variétés d'olivier de table dans le centre Tunisien," Annales de l'INRGREF, vol. 6, pp. 111-125, 2004.

[8] I. Nagel, F. Lang, M. Kaupenjohann, K. H. Pfeffer, F. Cabrera, and L. Clemente, "Guadiamar toxic flood: factors that govern heavy metal distribution in soils," Water, Air, and Soil Pollution, vol. 143, no. 1-4, pp. 211-224, 2003.

[9] T. W. Speir, A. P. Van Schaik, H. J. Percival, M. E. Close, and L. Pang, "Heavy metals in soil, plants and groundwater following high-rate sewage sludge application to land," Water, Air, and Soil Pollution, vol. 150, no. 1-4, pp. 319-358, 2003.

[10] A. Bahri, "Utilization of treated wastewaters and sewage sludge in agriculture in Tunisia," Desalination, vol. 67, pp. 233-244, 1987.

[11] USSL (United States Salinity Laboratory Staff), Diagnosis and Improvement of Saline and Alkali Soils, vol. 60 of USDA Handbook, USSL, Washington, DC, USA, 1954. 
[12] A. M. El-Gazzar, E. M. El-Azab, and M. Sheha, "Effect of irrigation with fractions of sea water and drainage water on growth and mineral composition of young grapes, guavas, oranges and olives," Alexandria Journal of Agricultural Research, vol. 27, pp. 207-219, 1979.

[13] M. Benlloch, F. Arboleda, D. Barranco, and R. Fernandezescobar, "Response of young olive trees to sodium and boron excess in irrigation water," Hortscience, vol. 26, pp. 867-870, 1991.

[14] D. Charfi, A. Trigui, and K. Medhioub, "Effects of irrigation with treated wastewater on olive trees cv Chemlali of Sfax at the station of el hajeb," Acta Horticulturae, vol. 474, pp. 385390, 1999.

[15] N. M. Al-Gazzaz, Long-term irrigation effect of Khirbit EsSamra Effluent Water on soil and olive (Olea europaea L.) quality, M.S. thesis, Faculty of Science, University of Jordan, 1999.

[16] J. M. Murillo, R. López, J. E. Fernández, and F. Cabrera, "Olive tree response to irrigation with wastewater from the table olive industry," Irrigation Science, vol. 19, no. 4, pp. 175-180, 2000.

[17] M. H. Loupassaki, K. S. Chartzoulakis, N. B. Digalaki, and I. I. Androulakis, "Effects of salt stress on concentration of nitrogen, phosphorus, potassium, calcium, magnesium, and sodium in leaves, shoots, and roots of six olive cultivars," Journal of Plant Nutrition, vol. 25, no. 11, pp. 2457-2482, 2002.

[18] K. Al-Absi, M. Qrunfleh, and T. Abu-Sharar, "Mechanism of salt tolerance of two olive (Olea europaea L.) cultivars as related to electrolyte and toxicity," Acta Horticulturae, vol. 618, pp. 281-290, 2003.

[19] K. M. Al-Absi, F. M. Al-Nasir, and A. Y. Mahadeen, "Mineral content of three olive cultivars irrigated with treated industrial wastewater," Agricultural Water Management, vol. 96, no. 4, pp. 616-626, 2009.

[20] M. Zeiner, I. Steffan, and I. J. Cindric, "Determination of trace elements in olive oil by ICP-AES and ETA-AAS: a pilot study on the geographical characterization," Microchemical Journal, vol. 81, no. 2, pp. 171-176, 2005.

[21] C. Benincasa, J. Lewis, E. Perri, G. Sindona, and A. Tagarelli, "Determination of trace element in Italian virgin olive oils and their characterization according to geographical origin by statistical analysis," Analytica Chimica Acta, vol. 585, no. 2, pp. 366-370, 2007.

[22] A. Rhouma, M. Gharsallaoui, and M. Khlif, "Etude de l'effet de stockage des olives des deux variétés chemleli et chetoui sur les caractéristiques de leur huile," Revue Ezzitouna, vol. 10, pp. 52-59, 2005.

[23] ONAS, Office National d'Assanissement, Sfax, Tunisia, 2003.

[24] R. K. Rattan, S. P. Data, P. K. Chhonkar, K. Suribabu, and A. K. Singh, "Long term impact of irrigation with sewage effluents on heavy metal content in soil, crops and groundwater-a case study," Agriculture, Ecosystems \& Environment, vol. 13, pp. 236-242, 2005.

[25] Z. Wiesman, D. Itzhak, and N. Ben Dom, "Optimization of saline water level for sustainable Barnea olive and oil production in desert conditions," Scientia Horticulturae, vol. 100, no. 1-4, pp. 257-266, 2004.

[26] K. S. Chartzoulakis, G. Psarras, S. Vemmos, and M. Loupassaki, "Effects of salinity and potassium supplement on photosynthesis, water relations and $\mathrm{Na}, \mathrm{Cl}, \mathrm{K}$ and carbohydrate concentration of two olive cultivars," Agricultural Research, vol. 27, pp. 75-84, 2004.

[27] K. S. Chartzoulakis, "Salinity and olive: growth, salt tolerance, photosynthesis and yield," Agricultural Water Management, vol. 78, no. 1-2, pp. 108-121, 2005.
[28] "ECC regulation No 1989/2003 of 6 November 2003 amending Regulation (EEC) No 2568/91 on the characteristics of olive oil and olive-pomace oil and on the relevant methods of analysis," Official Journal of the European Union, vol. 295, pp. 57-77, 2003.

[29] M. Gharsallaoui, C. Benincasa, M. Ayadi, E. Perri, M. Khlif, and S. Gabsi, "Study on the impact of wastewater irrigation on the quality of oils obtained from olives harvested by hand and from the ground and extracted at different times after the harvesting," Scientia Horticulturae, vol. 128, no. 1, pp. 23-29, 2011.

[30] W. W. Christie, The Preparation of Derivatives of Fatty Acids. In Gas Chromatography and Lipids, The Oily Press, Ayr, Scotland, 1998.

[31] S. J. Huang and S. J. Jiang, "Determination of Zn, Cd and $\mathrm{Pb}$ in vegetable oil by electrothermal vaporization inductively coupled plasma mass spectrometry," Journal of Analytical Atomic Spectrometry, vol. 16, no. 6, pp. 664-668, 2001.

[32] M. Khlif, N. Grati-Kammoun, and M. El Euch, "Effet de la durée de stockage des olives sur la qualité de l'huile," Ezzaitouna, vol. 2, no. 1-2, article 102, pp. 1-9, 1996.

[33] A. Rhouma, M. Gharsallaoui, and M. Khlif, "Etude de l'effet de stockage des olives des deux variétés chemleli et chetoui sur les caractéristiques de leur huile," Revue Ezzitouna, vol. 10, pp. 52-59, 2005.

[34] M. Murillo, Z. Benzo, E. Marcano, C. Gomez, A. Garaboto, and C. Marin, "Determination of copper, iron and nickel in edible oils using emulsified solutions by ICP-AES," Journal of Analytical Atomic Spectrometry, vol. 14, no. 5, pp. 815-820, 1999.

[35] J. R. Castillo, M. S. Jiménez, and L. Ebdon, "Semiquantitative simultaneous determination of metals in olive oil using direct emulsion nebulization," Journal of Analytical Atomic Spectrometry, vol. 14, no. 9, pp. 1515-1518, 1999.

[36] S. Dabbou, I. Rjiba, A. Nakbi, N. Gazzah, M. Issaoui, and M. Hammami, "Compositional quality of virgin olive oils from cultivars introduced in Tunisian arid zones in comparison to Chemlali cultivars," Scientia Horticulturae, vol. 124, no. 1, pp. 122-127, 2010.

[37] M. Issaoui, G. Flamini, F. Brahmi et al., "Effect of the growing area conditions on differentiation between Chemlali and Chétoui olive oils," Food Chemistry, vol. 119, no. 1, pp. 220225, 2010 .

[38] H. Manaï, F. M. Haddada, A. Trigui, D. Daoud, and M. Zarrouk, "Compositional quality of virgin olive oil from two new Tunisian cultivars obtained through controlled crossings," Journal of the Science of Food and Agriculture, vol. 87, no. 4, pp. 600-606, 2007.

[39] S. Dabbou, S. Dabbou, H. Chehab et al., "Chemical composition of virgin olive oils from Koroneiki cultivar grown in Tunisia with regard to fruit ripening and irrigation regimes," International Journal of Food Science and Technology, vol. 46, no. 3, pp. 577-585, 2011.

[40] R. Ansari, T. G. Kazi, M. K. Jamali et al., "Variation in accumulation of heavy metals in different verities of sunflower seed oil with the aid of multivariate technique," Food Chemistry, vol. 115, no. 1, pp. 318-323, 2009.

[41] A. N. Anthemidis, V. Arvanitidis, and J. A. Stratis, "On-line emulsion formation and multi-element analysis of edible oils by inductively coupled plasma atomic emission spectrometry," Analytica Chimica Acta, vol. 537, no. 1-2, pp. 271-278, 2005. 
[42] D. Mendil, O. D. Uluozlu, M. Tuzen, and M. Soylak, "Investigation of the levels of some element in edible oil samples produced in Turkey by atomic absorption spectrometry," Journal of Hazardous Materials, vol. 165, no. 1-3, pp. 724-728, 2009.

[43] European Commission. Regulation (EC), Official Journal of the European Union, 1881/2006; Section 3-Metals, item 3.1.14, p. 21, 2006. 


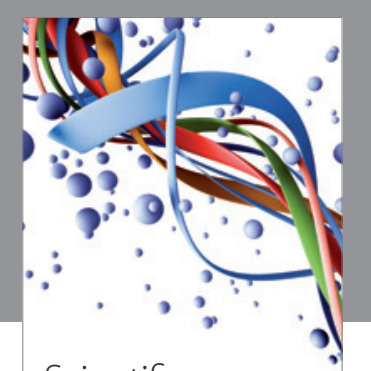

Scientifica
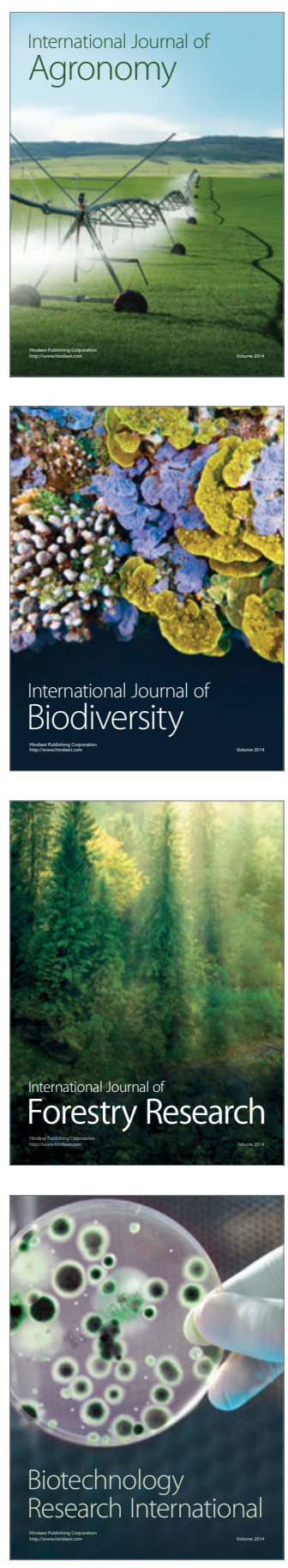
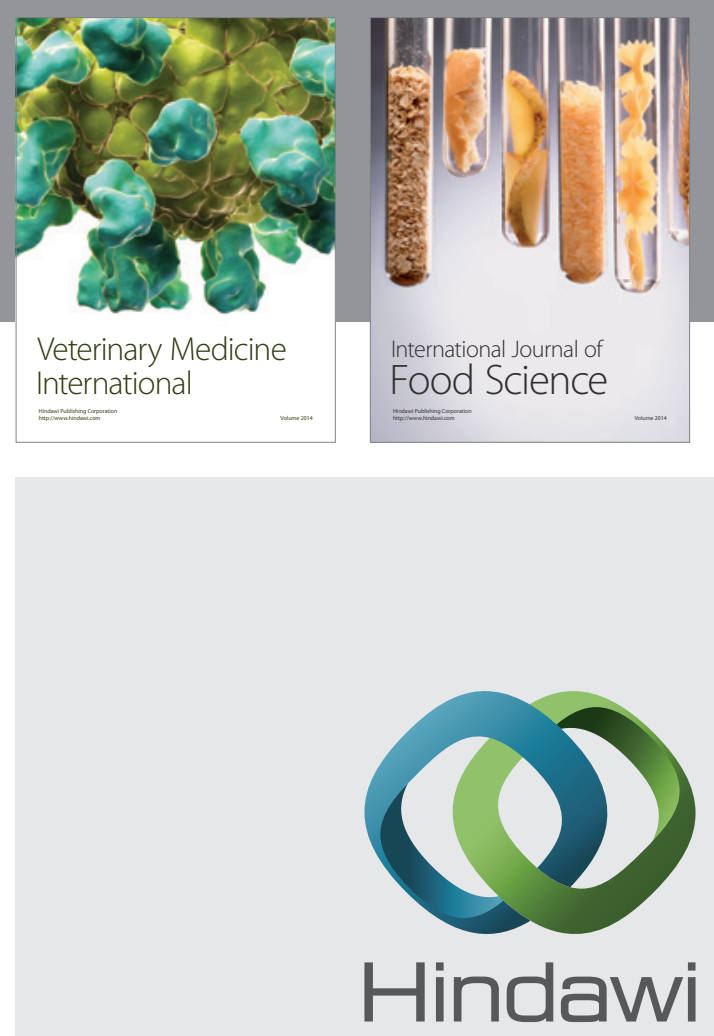

Submit your manuscripts at

http://www.hindawi.com
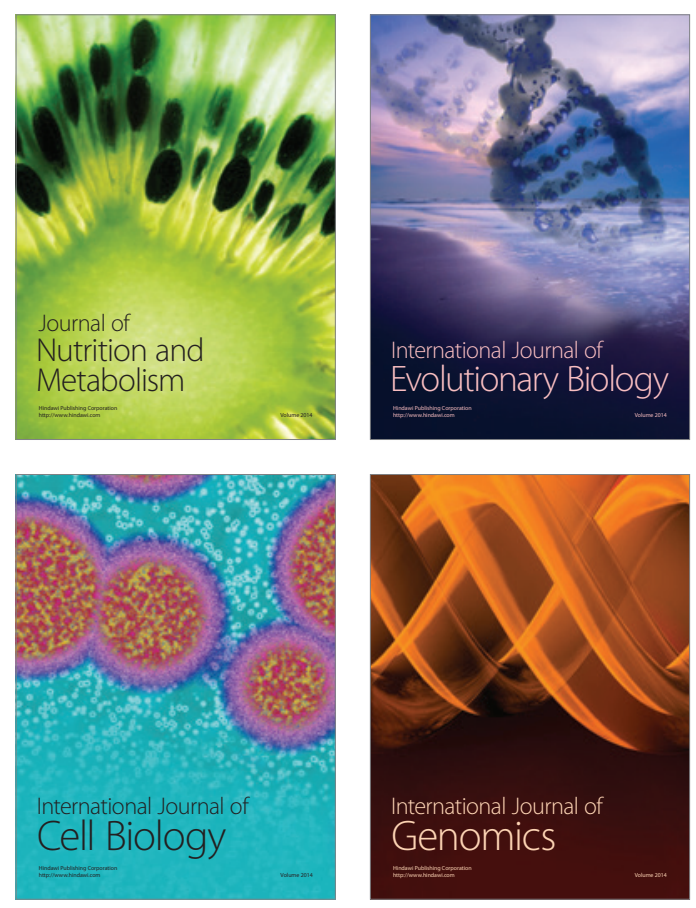
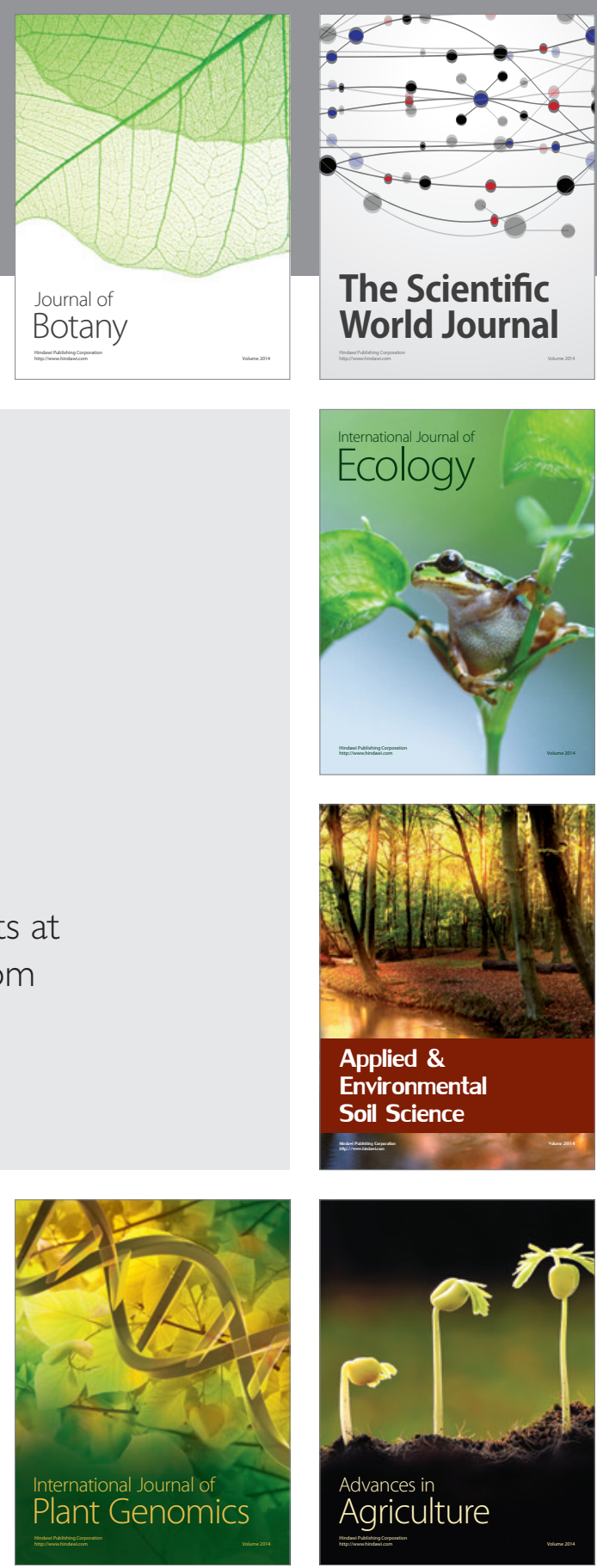

The Scientific World Journal
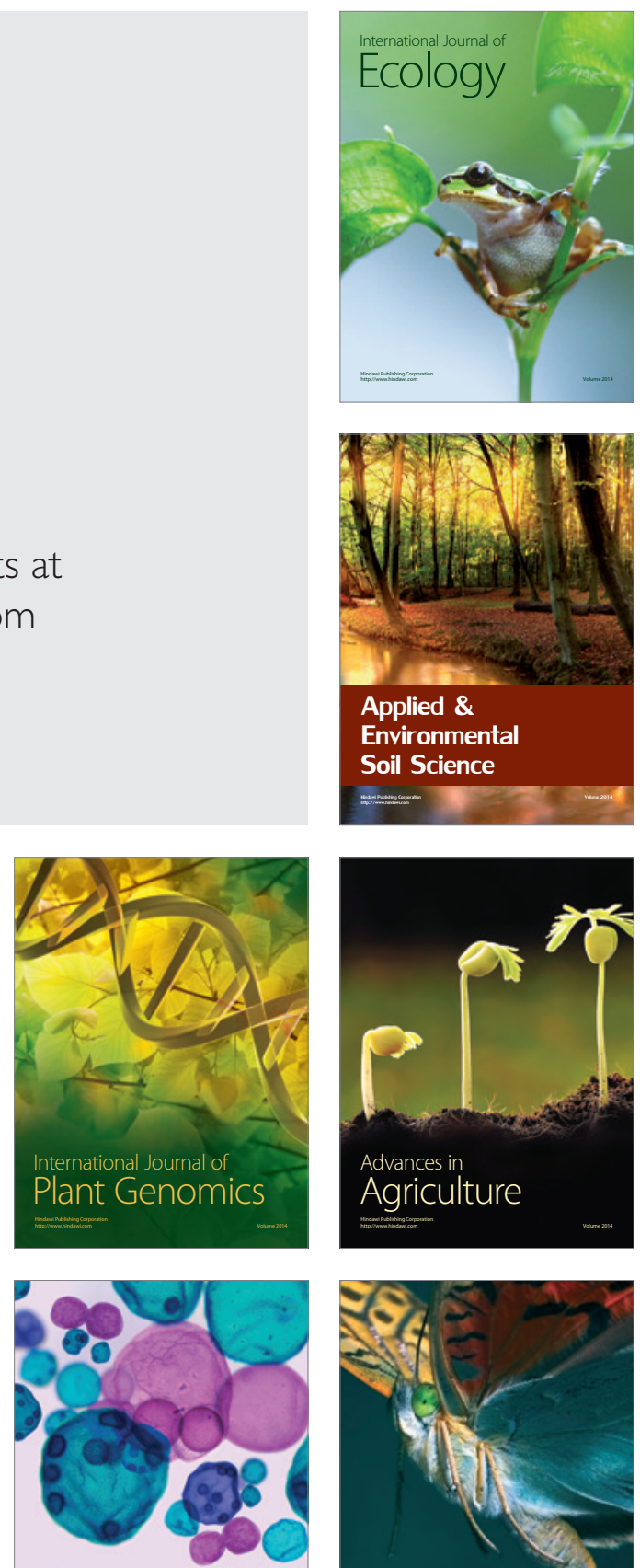

International Journal of Microbiology

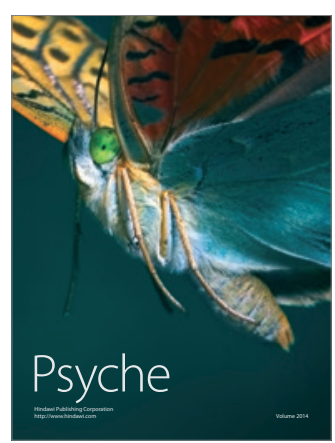

